\title{
Protection of the white-nest swiftlet Aerodramus fuciphagus in the Andaman Islands, India: an assessment
}

\author{
S. MANCHI and R. SANKARAN
}

\begin{abstract}
International trade of swiftlet nests has affected wild populations of edible-nest swiftlets throughout their range. The white-nest swiftlet Aerodramus fuciphagus of the Andaman and Nicobar Islands lost $80 \%$ of its population in the 1990s. Conservation efforts for the species were initiated in 2000, with the active involvement of former nest collectors. To measure the efficacy of protection measures we collected data on the swiftlet, using the nest count method. We monitored annual breeding populations in 28 protected caves on Chalis-ek and one on Interview Island during 2000-2008, and in 168 unprotected caves on Baratang and Interview Islands during February-April 2008. The swiftlet population in protected caves increased by $39 \%$, whereas it declined by $74 \%$ in unprotected caves. Nearly $61 \%$ of the 152 caves on Baratang Island were abandoned by the swiftlet during 1997-2008. This study highlights the importance of extending protection to the unprotected caves on the Andaman and Nicobar Islands.
\end{abstract}

Keywords Aerodramus fuciphagus, Andaman and Nicobar Islands, cave, edible-nest swiftlet, livelihood generation, nest, participatory conservation, sustainable harvesting

\section{Introduction}

B uilt of saliva, the edible nests of swiftlets have been used B in Chinese cuisine and pharmacy since the 16 th century (Lau \& Melville, 1994; Nguyen et al., 2002). By the early 18th century there was a great demand for these nests, resulting in uncontrolled nest-collection throughout the global range of the species concerned (Lau \& Melville, 1994; Gausset, 2004; Hobbs, 2004). Edible-nest swiftlets occur from the western Indian Ocean to southern continental Asia, Indonesia, northern Australia and New Guinea, and on islands of the West and South Pacific. Overharvesting of nests has resulted in a sharp decline in populations of edible-nest swiftlets across their range, including India,

S. MANCHI (Corresponding author) and R. SANKARAN* Sálim Ali Centre for Ornithology and Natural History, Anaikatty P.O., Coimbatore 641 108, India. E-mail ediblenest@gmail.com

* Deceased 17 January 2009

Received 16 November 2010. Revision requested 14 January 2011 Accepted 9 March 2011. First published online 4 February 2014. leading to local extinction in some cases (Koon \& Cranbrook, 2002; Nguyen et al., 2002).

The Apodiforms are one of the most difficult groups of birds to identify and there is continuing discussion about the taxonomic status of many species in the group. Here we follow the classification of Brooke (1970), Josep et al. (1999) and Thomassen et al. (2005), who placed the echolocating edible-nest swiftlets in the genus Aerodramus and the nonecholocating glossy swiftlets in the genus Collocalia.

Because of the high price fetched for its nest of pure saliva the white-nest swiftlet Aerodramus fuciphagus (earlier known as Collocalia fuciphaga; Nguyen et al., 2002) has been greatly affected by nest collection and the species is a conservation priority (Sankaran, 2001). The black-nest swiftlet Aerodramus maximus and the Indian edible-nest swiftlet Aerodramus unicolor, which also use saliva to build their nests but add their preened feathers, are similarly threatened by nest collection (Jagdeep et al., 2002; Koon \& Cranbrook, 2002; Nguyen et al., 2002; Sankaran \& Manchi, 2008).

Although the wild population of A. fuciphagus is decreasing the decline does not approach the threshold for Vulnerable and the species is therefore categorized as Least Concern on the IUCN Red List (BirdLife International, 2012). In addition, semi-domesticated populations are tended by local people, in man-made structures, for harvest of the edible nests.

The Andaman and Nicobar Islands in the northeastern Indian Ocean are the western limit of the whitenest swiftlet's range (Koon \& Cranbrook, 2002) and the subspecies A. fuciphagus inexpectatus is endemic to these islands. The islands are peaks of a continuous submerged ridge that is the southern extension of the Arakan Yoma mountain range (Saldanha, 1989; Jayaraj \& Andrews, 2005) extending to Sumatra in the south. There are 385 known caves on the Andaman and Nicobar Islands, of which 291, distributed over the entire archipelago, are inhabited by the white-nest swiftlet, (Sankaran, 1998; Manchi \& Sankaran, $2009 \mathrm{~b})$. Since the late 17 th or early 18 th century, Burmese and Thai poachers have exploited the nests from these caves. More recently Karen, Ranchi and Bengali settlers have exploited the nests (Sankaran, 1998, 2001; nest collectors, pers. comms). During the 1980 os the intensity of nest collection increased to twice per week during the nesting season, resulting in an $80 \%$ decline in the population during the 1990 (Sankaran, 2001). Across its range populations of the white-nest swiftlet have declined because of indiscriminate 
nest harvesting (Lau \& Melville, 1994; Sankaran, 2001; Koon \& Cranbrook, 2002; Nguyen et al., 2002; Gausset, 2004; Hobbs, 2004), and conservation measures such as leasing and management of caves by local people have failed to protect the swiftlets in many locations (Koon \& Cranbrook, 2002; Nguyen et al., 2002).

A conservation action plan that employs local nest collectors to protect the swiftlet's nests during its breeding season began in the Andaman Islands in 2000 (Sankaran \& Manchi, 2008). Here we investigate and discuss the efficacy of this protection and recommend management plans for the conservation of the white-nest swiftlet on these islands.

\section{Methods}

We carried out our assessment at three sites in the North and Middle Andaman Islands: Chalis-ek, Interview Island and Baratang Island (Fig. 1). An initial survey of 241 caves, in 1997 (Sankaran, 1998), was used as a baseline for comparative purposes. Of these caves, 28 on Chalis-ek and one on Interview Island have been guarded for conservation of the white-nest swiftlet since 2001 and 2000, respectively. We refer to these caves as protected caves. In addition we surveyed 168 caves (16 on Interview Island and 152 on Baratang Island) where the white-nest swiftlet is not protected. We refer to these caves as unprotected. There are no unprotected caves on Chalis-ek.

Chalis-ek contains a group of inland limestone caves in a hill at Pattilevel near Ramnagar in the south-east of North Andaman Island (Sankaran, 1998, 2001; Manchi \& Sankaran, 2009b). Of the 30 known caves in the hill, 28 are occupied by the white-nest swiftlet and have been under continuous protection since 2001, particularly during the breeding season of January-July (Sankaran \& Manchi, 2008; Manchi, 2009). These caves are protected by 14 former nest collectors who operate from eight temporary camps at the base of the hill.

The $133 \mathrm{~km}^{2}$ Interview Island is the largest Wildlife Sanctuary on the Andaman and Nicobar Islands (Pande et al., 1991) and is the westernmost uninhabited island of North and Middle Andaman. This island has at least 34 caves, of which 18 are known to host breeding colonies of the white-nest swiftlet (Sankaran, 1998; Sankaran \& Manchi, 2008; Manchi, 2009). One of the caves (Manchi \& Sankaran, $2009 \mathrm{~b}$ ) has been under protection since 2000 (during January-September; Sankaran \& Manchi, 2008). The cave is protected by four guards and the two openings are each guarded by a temporary camp during the breeding season. Of the other 17 caves occupied by swiftlets we were able to survey 16.

Baratang Island, in the southernmost Middle Andaman Islands, has 172 caves in an area of $1 \mathrm{~km}^{2}$ between Wraffter's

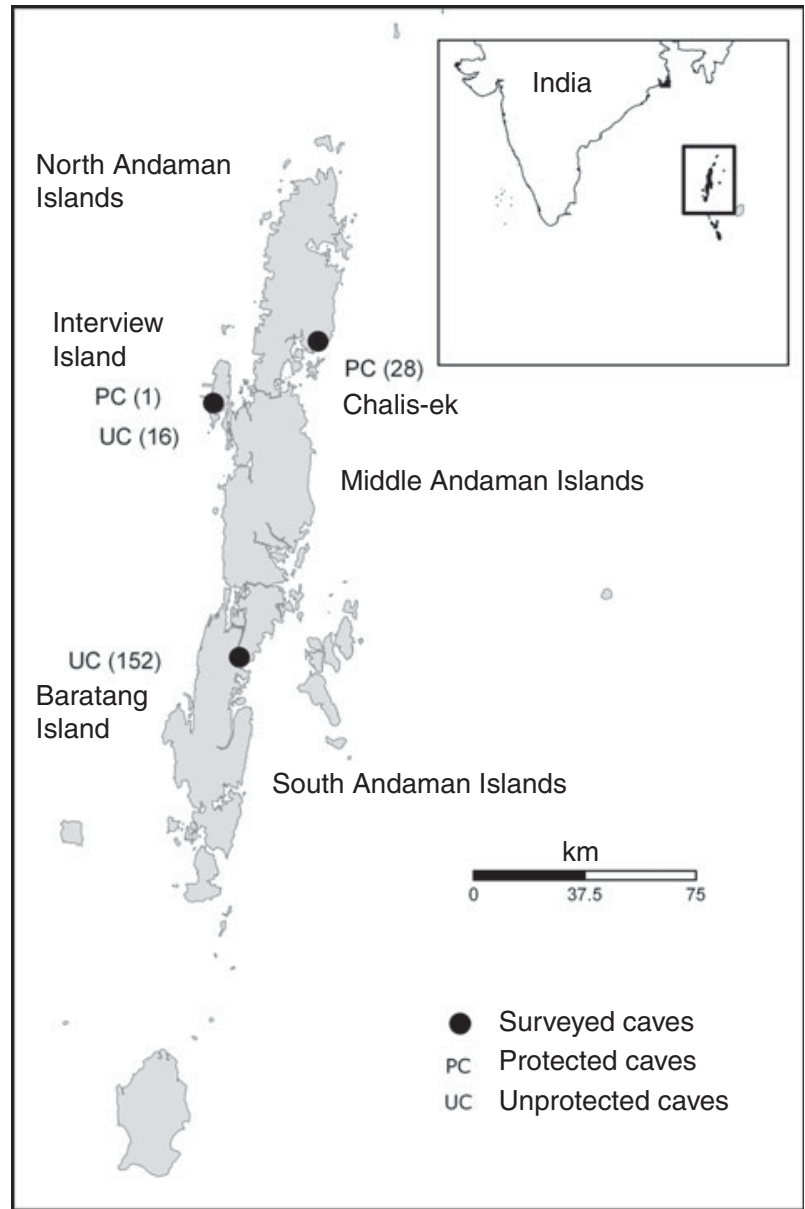

FIG. 1 The location of the three survey sites at Chalis-ek, Interview Island and Baratang Island in the North and Middle Andaman Islands. The rectangle on the inset indicates the location of the main map in the Indian Ocean.

Creek and Naya Dera. Most of these caves are clefts and cracks of only 1-2 m wide but they are 10-12 $\mathrm{m}$ deep and extend horizontally for up to $20 \mathrm{~m}$ (Sankaran, 1998; Manchi \& Sankaran, 2009b). We surveyed 152 of these caves during peak nest construction and the egg-laying season of February-April 2008. Nest collectors confirmed the absence of swiftlets in the other, unsurveyed caves. We surveyed the protected caves every year during 2000-2008 on Interview Island and those on Chalis-ek during 2001-2008. All accessible nests in the protected caves were observed daily to record the number of eggs laid and hatched, and the number of chicks fledged. The unprotected caves were surveyed in the breeding season of 2008. Breeding populations were estimated by the nest-count method (Sankaran, 1998, 2001). Nests were counted repeatedly during the nest-construction and egg-laying periods and the maximum count was considered to be the breeding population. As these swiftlets are known to be monogamous (Koon \& Cranbrook, 2002) each nest corresponds to a pair of swiftlets. Field assistants (former or current nest-collectors) 
were involved in the surveys, helping us to locate nests and nest marks. As the nests in unprotected caves are subjected to illegal nest-collection, the populations were estimated by counting partially built nests and marks of fresh saliva on the nesting sites.

\section{Data analysis}

We compared the breeding populations of the white-nest swiftlet in the protected and unprotected caves. We estimated the mean number of chicks fledged per nest as the total number of chicks fledged divided by the total number of nests under daily observation. As no systematic recording of the swiftlet was carried out in 2000 on Interview Island we omitted this year from the analysis. Hence for 2001-2008 there are data for the 29 protected caves on Chalis-ek (28) and Interview Island (1), and for 2008 there are data for 168 unprotected caves on Baratang (152) and Interview Island (16).

\section{Results}

During 2001-2008 there was a $39 \%$ increase overall in the white-nest swiftlet population in the 29 protected caves ( 28 on Chalis-ek and one on Interview Island), with a mean annual growth rate of $5 \pm$ SE $2 \%$. On average $1.37 \pm$ SE 0.7 chicks per nest fledged annually during 2001-2008. In the 28 caves monitored on Chalis-ek the population increased by 54\% during 2001-2008, with a mean annual growth rate of $7 \pm \mathrm{SE} 4 \% ; 4,891$ protected nests yielded the successful fledging of 5,681 chicks $(1.15 \pm \mathrm{SE} 0.03$ chicks per nest per year). However, there was a decline in the mean annual population growth rate from $13 \pm$ SE $8 \%$ during 2002-2004 to $2 \pm$ SE $0.6 \%$ during 2005-2008 (Fig. 2a). Although nearly 2,050 chicks fledged from 1,364 nests in the cave on Interview island during 2000-2008 (1.47 \pm SE 0.11 chicks per nest per year), the population declined by $54 \%$ during 2001-2005 but increased by $12 \%$ during 2006-2008 (Fig. 2b).

There was a $74 \%$ decline overall in the number of nests in the 168 unprotected caves between 1997 (Sankaran, 1998) and 2008 (from 2,109 nests). The unprotected populations of white-nest swiftlet in the 16 caves on Interview Island declined by $78 \%$ (from 310 nests) and those in the 152 caves on Baratang Island declined by $73 \%$ (from 1,799 nests). Nearly $61 \%$ of the 152 caves on Baratang Island were abandoned during this time.

\section{Discussion}

In the absence of regulation, potential extinction of the white-nest swiftlet on the Andaman and Nicobar Islands by 2025 was predicted (Sankaran, 1998, 2001). In 2001, therefore, 14 nest collectors whose sole financial dependence was on the collection of edible nests were employed

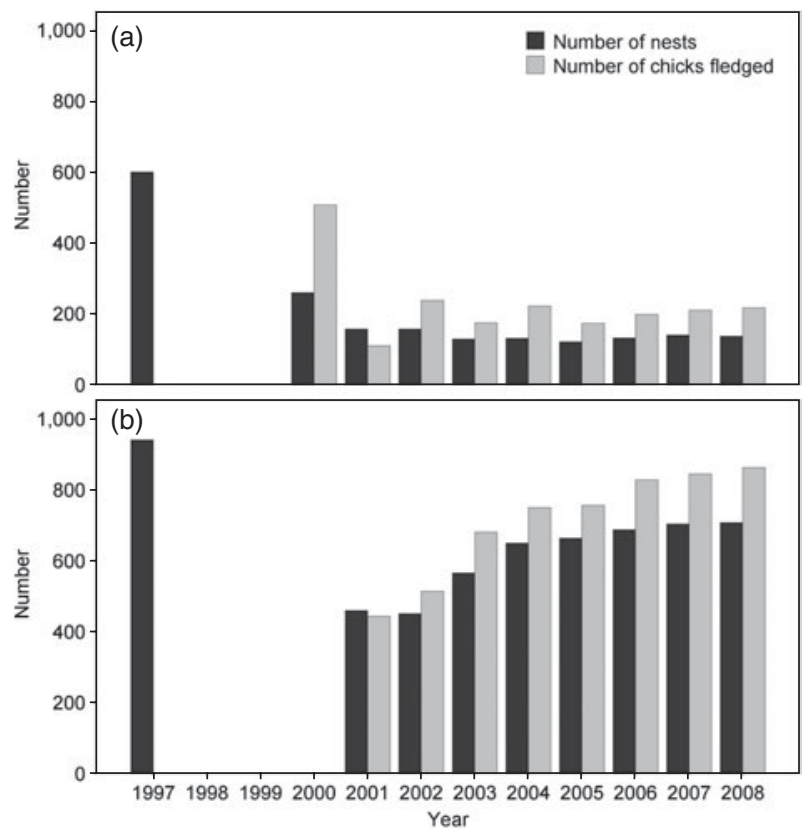

Fig. 2 Population of the white-nest swiftlet Aerodramus fuciphagus in 28 protected caves on Chalis-ek (a) and one cave on Interview Island (b) during 2001-2008 (see Fig. 1 for locations). Protection commenced in 2001.

to protect and monitor nests until the end of the breeding season. Unlike the South-east Asian practice of leasing out caves to nest collectors (Koon \& Cranbrook, 2002; Nguyen et al., 2002; Hobbs, 2004), nest collectors in the Andaman and Nicobar Islands were employed during the breeding season, by the local Forest Department, to protect the nests from poachers. The operation was monitored by scientists and Forest Department personnel. The nests from these protected caves were harvested only after fledging of at least one brood, in contrast to the South-east Asian practice of harvesting several times in a season (Koon \& Cranbrook, 2002; Nguyen et al., 2002; Hobbs, 2004).

The legal protection of the white-nest swiftlet, along with other two swiftlet species, under Schedule-I, Endangered Species list, of the Indian Wildlife (Protection) Act (1972) hindered community participation in these conservation efforts as involvement of nest protectors and sustainable harvesting were not legal. Sustainable harvesting of the edible nests was crucial to ensure protection, however, and therefore efforts were directed towards delisting A. fuciphagus inexpectatus from the Act. The nest protectors realized that protecting caves and allowing successful breeding of the white-nest swiftlet is the only way to ensure a continuous and sustainable supply of nests. Therefore protection continued, with the assurance of legal nest-collection opportunities in the future. Our results demonstrate that this protection resulted in an increase in the numbers of the white-nest swiftlet in the protected caves.

The swiftlet populations at the two protected sites behaved differently. The population at Chalis-ek declined 
during the breeding season following the commencement of protection. This was attributed to the absence of yearlings in the breeding season subsequent to their birth; they would usually return to their parental cave at the end of the season and breed in the following season (Sankaran \& Manchi, 2008; Manchi, 2009). The population increased from 2002 onwards until the earthquake of December 2004, which altered the structure and microclimate of the caves and appeared to lead to a decline in the population (Manchi \& Sankaran, 2009b). Nevertheless, the population thereafter increased.

After a $57 \%$ decline from 1997 (Sankaran, 1998) to 2000 there were 260 breeding pairs in the cave on Interview Island when protection commenced in 2000 . In contrast to Chalisek, the white-nest swiftlet population at this site gradually declined despite protection and successful fledging each year. The main cause of this decline was a wooden scaffold built inside the cave for monitoring the nests; the scaffold became a perch for the Andaman brown hawk owl Ninox scutulata obscura and red-tailed trinket snake Gonyosoma oxycephalum, from which they accessed the cave roof to predate the swiftlet chicks (Grimmett et al., 1998; Whitaker \& Captain, 2004; Manchi \& Sankaran, 2009a). The scaffold was removed at the end of the breeding season in August 2005. A second cause of decline was the presence of the camps at the cave mouths and above the cave. Walking, loud noises and chopping of firewood directly over the nesting site may have disturbed the swiftlets and discouraged new breeding pairs from selecting the cave for nesting. The two camps were therefore moved 5-15 $\mathrm{m}$ away from the cave mouths at the end of the breeding season in August 2005. The white-nest swiftlet population subsequently increased by $10 \%$ during $2006-2008$.

Unregulated nest collection has resulted in declines of edible-nest swiftlets across South-east Asia (Lau \& Melville, 1994; Koon \& Cranbrook, 2002; Nguyen et al., 2002; Gausset, 2004; Hobbs, 2004). Extrapolation of the estimated loss of 2,249 breeding pairs of the 3,716 breeding pairs recorded across the Andaman Islands during the breeding season (January-August) of 1997 indicated the potential extinction of the species from the Andaman and Nicobar Islands by 2025 (Sankaran, 1998). Of the 152 caves inhabited by the white-nest swiftlet in Wraffters Creek on Baratang Island (Sankaran, 1998), the species had disappeared from $>60 \%$ by 2000 because of unregulated collection despite the legal protection afforded to the species. However, on Interview Island swiftlets remained even in unprotected caves. This may be attributed to post-natal dispersal of successfully fledged chicks from the one protected cave to the unprotected caves (Sankaran \& Manchi, 2008).

In November 2009 the joint effort of scientists and managers, and the involvement of local people, resulted in the conditional delisting of the white-nest swiftlet from the
Endangered List of Schedule-I of the Indian Wildlife (Protection) Act (1972) for experimental purposes. This means that the participatory conservation programme can continue, with the support of the local Forest Department, and ex situ populations of the species can be developed. The ex situ populations will be developed in the same manner as elsewhere in South-east Asia, with the construction of buildings that mimic the conditions of caves ('swiftlet houses'; Sankaran \& Manchi, 2008). In these houses cross-fostering techniques will be used to initiate breeding of the white-nest swiftlet (Sankaran \& Manchi, 2008), as has been practised elsewhere (Koon \& Cranbrook, 2002; Nguyen et al., 2002). This move may eventually lead to sustainable harvesting and trade of the edible nests, thereby providing a livelihood to the nest protectors. Our study has shown that active protection with community participation can prevent unrestrained collection of the nests of this swiftlet and could ensure the future stability of the population on the Andaman and Nicobar Islands. As of 2013, conservation of the white-nest swiftlet on the Andaman and Nicobar Islands continues, with successful protection by the nest collectors, but protection needs to be expanded to the unprotected caves.

\section{Acknowledgements}

We acknowledge the Department of Environment and Forests, Andaman and Nicobar Islands for their financial support and involvement in the conservation of the white-nest swiftlet, the swiftlet protection team (Tapori, Andrew, Thowthow, Mangal, Tercius, Jerom, the late Pius Induwar, Igneceus, Joseph, Deus, Rijus, Pitrus, Robin, Parimal, Shorod and Bhuvan) for their contributions to the conservation programme, Saw Alexander for his involvement during the study, and Phulonjee from Webby and Rajender and Jems from Wraffter's Creek for their assistance in surveying unprotected caves. We acknowledge Archana Waran, Rachna Chandra and Harshada Pethe, and Dr P.A. Azeez, Dr P. Pramod, Dr Honnavalli N. Kumara and Dr B.A.K. Prusty from SACON, and Dr M. Ananda Kumar from the Nature Conservation Foundation for their support and comments. We thank Ms Akshaya Mane, SACON, for preparing the map. We dedicate this article to the late Mrs Rajyashri Sankaran and the late Yamini Sankaran for their contributions to the management of the protection camps and for motivating the nest protectors.

\section{References}

Birdife International (2012) Collocalia fuciphaga. In IUCN Red List of Threatened Species v. 2013.2. Http://www.iucnredlist.org [accessed 3 December 2013]. 
Brooke, R. K. (1970) Taxonomic and evolutionary notes on the sub-families, tribes, genera and subgenera of the swifts (Aves: Apodidae). Durban Museum Novitates, 9, 13-24.

ChнокаR, J.S. \& Pande, S.A. (2002) Taste for Swiftlet's Edible Nest is Lowering its Numbers. Http://news.nationalgeographic.co.uk/news/ 2002/08/0821_020822_swiftlet_2.html [accessed 17 December 2013].

Gausset, Q. (2004) Chronicle of a foreseeable tragedy: birds' nests management in the Niah caves (Sarawak). Human Ecology, 32, 487-507.

Grimmett, R., Inskipp, C. \& Inskipp, T. (1998) Handbook of Birds of the Indian Subcontinent. A. \& C. Black, London, UK.

Нов в, J.J. (2004) Problems in the harvest of edible birds' nests in Sarawak and Sabah, Malaysian Borneo. Biodiversity and Conservation, 13, 2209-2226.

Jayaraj, R.S.C. \& ANDrews, H.V. (eds) (2005) Andaman and Nicobar Islands Union Territory Biodiversity Strategy and Action Plan. Prepared under the National Biodiversity Strategy and Action Plan, Government of India-UNDP. Universities Press, Hyderabad, India.

Josep, D.H., Andrew, E. \& Sargatal, J. (1999) Handbook of the Birds of the World. Volume 5: Barn Owls to Hummingbirds. BirdLife International, Cambridge, UK.

Koon, L.C. \& Cranbrook, EARL of (2002) Swiftlets of Borneo: Builders of Edible Nests. Natural History Publications (Borneo), Kota Kinabalu, Malaysia.

Lau, A.S.M. \& Melville, D.S. (1994) International Trade in Swiftlet Nests. Traffic International and WWF, Cambridge, UK.

MANCHI, S. (2009) Breeding ecology of the edible-nest swiftlet Aerodramus fuciphagus and glossy swiftlet Collocalia esculenta in the Andaman Islands, India. $\mathrm{PhD}$ thesis. Bharathiyar University, Coimbatore, India.

Manchi, S. \& SAnkaran, R. (2009a) Predators of swiftlets and their nests in the Andaman and Nicobar Islands. Indian Birds, 5, 118-120.

ManCHI, S. \& Sankaran, R. (2009b) Impact of the 2004 earthquake on the limestone caves in North and Middle Andaman Islands. Current Science, 97, 1230-1234.

Nguyen, Q.P., Yen, V.Q. \& Voisin, J. (2002) The White-Nest Swiftlet and the Black-Nest Swiftlet. Société Nouvelle des Éditions Boubée, Paris, France.
Pande, P., Kothari, A. \& Singh, S. (eds) (1991) Directory of National Parks and Sanctuaries in Andaman and Nicobar Islands. Indian Institute of Public Administration, New Delhi, India.

Saldanha, C.J. (1989) Andaman, Nicobar and Lakshadweep. An Environmental Impact Assessment. Oxford \& IBH, New Delhi, India.

Sankaran, R. (1998) The Impact of Nest Collection on the Edible-Nest Swiftlet (Collocalia fuciphaga) in the Andaman and Nicobar Islands. Report to IUCN. Sálim Ali Centre for Ornithology and Natural History, Coimbatore, India.

SANKaran, R. (2001) The status and conservation of the edible-nest swiftlet (Collocalia fuciphaga) in the Andaman and Nicobar Islands. Biological Conservation, 97, 283-294.

Sankaran, R. \& Manchi, S. (2008) Conservation of the Edible-nest Swiftlets in the Andaman and Nicobar Islands. Report to the Department of Environment and Forest, Andaman and Nicobar Islands. Sálim Ali Centre for Ornithology and Natural History, Coimbatore, India.

Thomassen, H.A., Den Tex, R.-J., De Bakker, M.A.G. \& Povel, G.D.E. (2005) Phylogenetic relationships amongst swifts and swiftlets: a multi locus approach. Molecular Phylogenetics and Evolution, 37, 264-277.

Whitaker, R. \& Captain, A. (2004) Snakes of India: The Field Guide. Draco Books, Chennai, India.

\section{Biographical sketches}

SHIRISH MANCHI has been working for a decade on the conservation of the edible-nest swiftlet on the Andaman and Nicobar Islands. He has also studied the Narcondam hornbill and feral elephants on the Andaman Islands, and the lesser florican in the grasslands of Western and Central India. RAVI S A NKARAN worked on the conservation of threatened birds such as the lesser florican, the Nicobar megapode, the Narcondam hornbill and the edible-nest swiftlet, and initiated community conservation activities in Nagaland. His untimely demise in January 2009 was a great loss to conservation in India. 